\title{
Somatic cell score: gene polymorphisms and other effects in Holstein and Simmental cows
}

\author{
Jindřich Čítek ${ }^{1, \star}$, Michaela Brzáková ${ }^{2}$ Lenka Hanusová1 , Oto Hanuš ${ }^{3}$, Libor Večerek ${ }^{1}$, Eva Samková1, \\ Eva Jozová ${ }^{1}$, Irena Hoštičková ${ }^{1}$, Jan Trávníček ${ }^{1}$, Martin Klojda', and Lucie Hasoňová ${ }^{1}$
}

\footnotetext{
* Corresponding Author: Jindřich Čítek Tel: +420-38-777-2591

E-mail: citek@zf.jcu.cz
}

' Faculty of Agriculture, South Bohemia University, CZ37005 Ceske Budejovice, Czech Republic

2 Department Genetic and Animal Breeding Institute of Animal Science, CZ104 00 Praque, Czech Republic

${ }^{3}$ Dairy Research Institute, CZ16000 Prague Czech Republic

ORCID

Jindřich Čítek

https://orcid.org/0000-0003-4305-9160

Michaela Brzáková

https://orcid.org/0000-0002-7510-3480 Lenka Hanusová

https://orcid.org/0000-0002-8180-2456 Oto Hanuš

https://orcid.org/0000-0002-3616-7668 Libor Večerek

https://orcid.org/0000-0002-2069-4615

Eva Samková

https://orcid.org/0000-0002-9246-4456 Eva Jozová

https://orcid.org/0000-0001-9831-6537 Irena Hoštičková

https://orcid.org/0000-0001-7824-5794 Jan Trávníček

https://orcid.org/0000-0002-0557-0390 Martin Klojda

https://orcid.org/0000-0002-2756-2463

Lucie Hasoňová

https://orcid.org/0000-0001-7763-8609

Submitted Oct 14, 2020; Revised Feb 1, 2021 Accepted Apr 2, 2021
Objective: The aim of the study was to evaluate the influence of gene polymorphisms and nongenetic factors on the somatic cell score (SCS) in the milk of Holstein ( $\mathrm{n}=148)$ and Simmental $(n=73)$ cows and their crosses $(n=6)$.

Methods: The SCS was calculated by the formula SCS $=\log _{2}(S C C / 100,000)+3$, where SCC is the somatic cell count. Polymorphisms in the casein alpha S1 (CSN1S1), beta-casein (CSN2), kappa-casein (CSN3), beta-lactoglobulin (LGB), acyl-CoA diacylglycerol transferase 1 (DGAT1), leptin (LEP), fatty acid synthase (FASN), stearoyl CoA desaturase 1 (SCD1), and 1-acylglycerol-3-phosphate O-acyltransferase 6 (AGPAT6) genes were genotyped, and association analysis to the SCS in the cow's milk was performed. Further, the impact of breed, farm, year, month of the year, lactation stage and parity on the SCS were analysed. Phenotype correlations among SCS and milk constituents were computed by Pearson correlation coefficients.

Results: Only CSN2 genotypes $\mathrm{A}^{1} / \mathrm{A}^{2}$ were found to have significant association with the SCS $(\mathrm{p}<0.05)$, and alleles of CSN1S1 and DGAT1 genes $(\mathrm{p}<0.05)$. Other polymorphisms were not found to be significant. SCS had significant association with the combined effect of farm and year, lactation stage and month of the year. Lactation parity and breed had not significant association with SCS. The phenotypic correlation of SCS to lactose content was negative and significant, while the correlation to protein content was positive and significant. The correlations of SCS to fat, casein, nonfat solids, urea, citric acid, acetone and ketones contents were very low and not significant.

Conclusion: Only CSN2 genotypes, CSN1S1 and DGAT1 alleles did show an obvious association to the SCS. The results confirmed the importance of general quality management of farms on the microbial milk quality, and effects of lactation stage and month of the year. The lactose content in milk reflects the health status of the udder.

Keywords: Acyl-CoA Diacylglycerol Transferase 1 (DGAT1); Breed; Caseins; Dairy Cattle; Lactose; Milk

\section{INTRODUCTION}

Mastitis is one of the most crucial health problems in the dairy industry. It causes immense financial damages by decreasing the milk yield, untimely culling of dairy cows, and increasing treatment costs. Clinical and subclinical mastitis reduces the milk quality, interferes with the processing of milk and has the potential to endanger human health due to antibiotic residues [1]. For instance, under the Czech Republic (CR) conditions, with every increase in the somatic cell count (SCC) by $10^{5} \mathrm{~mL}^{-1}$, milk production is reduced by $51 \mathrm{~kg}$ per cow per lactation on average. Fat and protein contents are decreased, as is the payment price [2-4]. In the CR, the economic loss was estimated at 410 US dollars (USD) per cow with mastitis, which is equal to revenue from sales for 950 liters of milk at the milk price 
of 0.43 USD per liter. In the total losses inflicted by mastitis participate the lower takings from the sale of milk by $53 \%$, higher culling of cows (herd turnover, 20\%), higher costs for drugs and treatments (14\%), labor for the treatment of ill cows $(7 \%)$ and penalties on the farmer's milk price $(6 \%)$.

There are various causes of mastitis. From the perspective of cow breeds, the heritability of mastitis occurrence is unfortunately very low. In the Czech dairy cattle population, heritabilities of 0.10 and repeatabilities of 0.19 at the most were found [5]. The health status of the mammary gland is often assessed indirectly by SCC or somatic cell score (SCS), as the genetic correlation between SCC and clinical mastitis is often significant [6]. However, the heritabilities of these indicators are also usually very low. In the Czech dairy population, the heritabilities of SCS were 0.10 to 0.11 in Simmental and slightly higher in Holstein, at 0.10 to 0.14 , depending on the lactation stage [7]. A somewhat higher heritability of 0.19 was found in Brazilian Holstein [8].

Within this context, analyses of some major genes were performed, aimed at the identifying polymorphisms associated with udder health. The analyses are often performed together with those assessing milk performance [9]. The analysis focused inter alia on the polymorphisms in the mannose-binding lectin-associated serine protease 1 gene (MASP1). The authors found an association of g.5766A $>\mathrm{G}$ in the gene with milk protein percentage, but not with fat percentage, milk yield and SCS. Other authors found a significant impact of the polymorphisms in the lipocalin-2 (LCN2) gene on the average SCS of milk, but not on the milk yield, protein, fat and lactose contents, or the incidence of mastitis in cows $[10,11]$. These findings correspond with the fact that the LCN2 protein is secreted inter-alia by neutrophils. Another source reported the results of the analysis of three polymorphisms in the fatty acid desaturase 2 (FADS2) gene [12]. The enzyme plays a pivotal role in the biosynthesis of polyunsaturated fatty acids, and previous studies provided evidence that FADS2 was one of the most downregulated genes during negative energy balance in the liver of postpartum dairy cattle. The polymorphisms in the gene were significantly associated with test-day milk yield, fat percentage and 305day milk, fat and protein yields, protein percentage and SCS in the investigated population. Also the associations between polymorphisms in the gene and fatty acids contents were found $[13,14]$.

Obviously, there are some major genes with the potential to change milk production and to improve udder health and resistance against mastitis. Other authors have performed whole-genome searches and have identified a few regions, SNPs and genes associated with the indicators of infectious diseases incl. mastitis [15-17]. Next-generation sequencing enabled the establishment of a candidate gene set of 48 genes associated with mastitis in Holstein cattle [18].
The aim of this study was to evaluate the impact of different factors on the SCS in milk of Holstein and Simmental cows. The polymorphisms in the casein alpha S1 (CSN1S1), beta-casein (CSN2), kappa-casein (CSN3), beta-lactoglobulin ( $L G B$ ), acyl-CoA diacylglycerol transferase 1 (DGAT1), leptin $(L E P)$, fatty acid synthase (FASN), stearoyl CoA desaturase 1 gene (SCD1) and 1-acylglycerol-3-phosphate O-acyltransferase 6 (AGPAT6) genes were genotyped, and an association analysis was performed.

\section{MATERIALS AND METHODS}

\section{Animals}

All animal experiments were under supervision of the Institutional Animal Care and Use Committee of the Faculty of Agriculture of South Bohemia University, where the experiment was carried out, with approval number 22036/2019MZE-18134. DNA was extracted noninvasively from milk samples.

The group analyzed $(\mathrm{n}=227)$ consisted of cows of Holstein $(\mathrm{n}=148)$ and Simmental $(\mathrm{n}=73)$ breeds in the Czech Republic, and their crosses $(n=6)$. The cows were stabled in five farms in free stall housing $\left(\mathrm{n}_{1}=49 ; \mathrm{n}_{2}=31 ; \mathrm{n}_{3}=56 ; \mathrm{n}_{4}=\right.$ $50 ; n_{5}=41$ ). The cows calved in 2015 through 2017, and the milk samples were obtained repeatedly within two following lactations. The cows were in the 1st up to 6th lactation and were sampled throughout the year. The number of samples from one cow varied from one to five. The feed ratio consisted of maize silage, grass silage, hay and feed concentrates yearround.

\section{Sampling and milk analyses}

The individual cow milk samples were treated (preserved) with DF Control Microtabs tableted preservative preparate and $0.03 \%$ bronopol, transported under cold conditions $\left(<8^{\circ} \mathrm{C}\right)$ to the laboratory and analyzed for SCC. The analysis was performed in an accredited [19] laboratory for milk analysis that is owned by the Czech Moravian Breeder's Corporation on SCC $\left(10^{3} \mathrm{~mL}^{-1}\right)$ using a Somacount flow cytometer (Bentley Instruments, Chaska, MN, USA). The analysis was based on the photometry measurement of the complex reaction from the reaction between SCC DNA and ethidium bromide. These instruments were regularly calibrated according to relevant SCC reference values by using the so-called direct microscopic method and were also included in proficiency testing with regularly successful results [19-21]. The extended result uncertainty ( $95 \%$ probability level) was $\pm 9.3 \%$ for SCC $\leq 90010^{3} \mathrm{~mL}^{-1}$.

The milk composition, i.e., the contents of fat, crude protein, casein, lactose monohydrate, nonfat solids (NFS), urea, citric acid, acetone, and ketone as beta hydroxybutyrate, was determined in laboratories of the Czech Moravian Breeder's 
Corporation. Infrared spectroscopy by filter technology and by Fourier data transformation was applied. The instrumentation of Foss Electric (Hilleroed, Denmark) and Bentley Instruments (Chaska, MN, USA) was used. The instruments went through proficiency testing with regular successful results. The extended result uncertainties (95\% probability level) were $\pm 2.77 \%$ for fat $(0.101 \%$ for original unit as a gram per 100 grams), $\pm 2.59 \%$ for crude (total nitrogen content $\times 6.38$ ) protein $(0.085 \%)$, and $\pm 2.77 \%$ for lactose monohydrate $(0.115 \%)$.

\section{Genotyping}

DNA was isolated from the milk samples using a MagCore HF16 Plus DNA/RNA extractor (RBC Bioscience, New Taipei, Taiwan). Genotyping was performed by the PCR/RFLP method. CSN1S1 gene alleles B and C were genotyped according to the methods of Ardicli et al [22] and Kučerová et al [23]; CSN2 gene alleles A and B as in Medrano and Shar- row [24]; alleles $\mathrm{A}^{1}$ and $\mathrm{A}^{2}$ according to Miluchová et al [25]; CSN3 gene alleles A, B, C and $\mathrm{E}$ according to the methodology of Barroso et al [26]; LGB gene alleles A and B according to the methods of Strzalkowska et al [27]; DGAT1 gene alleles A (alanine) and $\mathrm{K}$ (lysine) as in Kuhn et al [28]; LEP gene alleles $\mathrm{M}$ and $\mathrm{W}$ as in Buchanan et al [29]; FASN gene alleles $A$ and $\mathrm{G}$ according to Roy et al [30]; and SCD1 gene alleles $\mathrm{C}$ and $\mathrm{T}$ according to the methods of Inostroza et al [31]. AGPAT6 gene alleles $\mathrm{C}$ and $\mathrm{T}$ were genotyped by using fragment analysis as in Littlejohn et al [22-32]. The sequences of primers used in the PCR and restriction endonucleases used for genotyping are given in Supplementary Table S1. The genotype and allelic frequencies were calculated (Table 1).

\section{Statistical analysis}

Somatic cell score was calculated by the formula:

$$
\mathrm{SCS}=\log _{2}(\mathrm{SCC} / 100,000)+3
$$

Table 1. Frequencies of genotypes and alleles

\begin{tabular}{|c|c|c|c|c|c|c|}
\hline Gene & Genotype & $\mathrm{n}^{1)}$ & Relative frequencies & $x^{2}$ & Allele & Allele frequencies \\
\hline \multirow[t]{2}{*}{ CSN1S1 } & $\mathrm{BB}$ & 201 & 88.55 & $0.367^{\text {ns }}$ & B & 0.943 \\
\hline & $\mathrm{BC}$ & 26 & 11.45 & & C & 0.057 \\
\hline \multirow[t]{3}{*}{ CSN2 } & $\mathrm{AA}$ & 9 & 3.96 & $0.269^{\text {ns }}$ & A & 0.220 \\
\hline & $A B$ & 82 & 36.12 & & B & 0.780 \\
\hline & $\mathrm{BB}$ & 136 & 59.91 & & & \\
\hline \multirow[t]{3}{*}{ CSN2 } & $A^{1} A^{1}$ & 23 & 10.85 & $1.956^{\text {ns }}$ & $A^{1}$ & 0.283 \\
\hline & $A^{1} A^{2}$ & 74 & 34.91 & & $A^{2}$ & 0.717 \\
\hline & $A^{2} A^{2}$ & 115 & 54.25 & & & \\
\hline \multirow[t]{7}{*}{ CSN3 } & $\mathrm{AA}$ & 100 & 44.05 & $3.408^{\text {ns }}$ & A & 0.676 \\
\hline & $A B$ & 98 & 43.17 & & B & 0.284 \\
\hline & $A E$ & 9 & 3.96 & & C & 0.004 \\
\hline & $\mathrm{BB}$ & 12 & 5.29 & & E & 0.035 \\
\hline & $B C$ & 2 & 0.88 & & & \\
\hline & $\mathrm{BE}$ & 5 & 2.20 & & & \\
\hline & $\mathrm{EE}$ & 1 & 0.44 & & & \\
\hline \multirow[t]{3}{*}{$L G B$} & $\mathrm{AA}$ & 8 & 3.52 & $39.725^{\star \star}$ & $A$ & 0.436 \\
\hline & $A B$ & 182 & 80.18 & & B & 0.564 \\
\hline & $\mathrm{BB}$ & 37 & 16.30 & & & \\
\hline \multirow[t]{2}{*}{ DGAT1 } & $\mathrm{AA}$ & 211 & 92.95 & $0.133^{\text {ns }}$ & A & 0.965 \\
\hline & $\mathrm{KA}$ & 16 & 7.05 & & K & 0.035 \\
\hline \multirow[t]{3}{*}{ LEP } & $\mathrm{MM}$ & 145 & 75.52 & $1.067^{\text {ns }}$ & $M$ & 0.862 \\
\hline & MW & 41 & 21.35 & & W & 0.138 \\
\hline & WW & 6 & 3.13 & & & \\
\hline \multirow[t]{2}{*}{ FASN } & $A G$ & 60 & 26.55 & $2.338^{\mathrm{ns}}$ & A & 0.133 \\
\hline & GG & 166 & 73.45 & & G & 0.867 \\
\hline \multirow[t]{3}{*}{$S C D$} & $\mathrm{CC}$ & 67 & 29.52 & $4.857^{\text {ns }}$ & C & 0.590 \\
\hline & $\mathrm{TC}$ & 134 & 59.03 & & $\mathrm{~T}$ & 0.410 \\
\hline & $\mathrm{TT}$ & 26 & 11.45 & & & \\
\hline \multirow[t]{3}{*}{ AGPAT6 } & $\mathrm{CC}$ & 69 & 31.36 & $21.560 * *$ & C & 0.648 \\
\hline & TC & 147 & 66.82 & & $\mathrm{~T}$ & 0.352 \\
\hline & TT & 4 & 1.82 & & & \\
\hline
\end{tabular}

CSN1S1, casein alpha S1; CSN2, beta-casein; CSN3, kappa-casein; LGB, beta-lactoglobulin; DGAT1, acyl-CoA diacylglycerol transferase 1; LEP, leptin; FASN, fatty acid synthase; SCD, stearoyl COA desaturase; AGPAT6, 1-acylglycerol-3-phosphate 0-acyltransferase 6; ns, Nonsignificant.

1) Number of animals with respective genotypes.

** Significant differences between genotype frequencies calculated on the basis of Hardy-Weinberg equilibrium and empirical frequencies ( $p<0.01$ ). 
where SCC, somatic cell count.

This method of evaluating individual SCCs is based on the work by Ali and Shook [33] and Shook [34]. The advantage of this evaluation lies in the normalization of the frequency distribution of SCC data for various statistical evaluations using parametric methods. The topic was further elaborated until the emergence of this transformation equation for recalculation of individual dairy cow SCCs on a linear score based on SCCs (SCSs) on a log-2 basis $[35,36]$. The main advantage of the SCS is the linearization of the SCC relationship to milk yield losses of dairy cows, mainly due to the occurrence of subclinical mastitis. The SCS scale was then used in scientific work as well as in practical breeding programs as a very suitable characteristic to control the dynamics of SCC development [37-42].

Statistical analyses were performed using SAS (SAS 9.3, SAS Institute, Cary, NC, USA). The data set contained repeated measurements of SCC transformed to SCS per cow obtained in the two following lactations. To analyze the effects of polymorphisms and other effects on the SCS, the linear mixed model (MIXED procedure of the SAS system with repeated measurements) and the least squared mean method were used. The model for the evaluation of multiple effect of all gene polymorphisms, breed and non-genetic effects was developed as follows:

$$
\begin{aligned}
\text { SCS }_{\mathrm{ijklmn}}= & \mu+C S C 1 S 1_{\mathrm{i}}+C S N 2 A B_{\mathrm{j}}+C S N 2 A 1 A 2_{k}+C S N 3_{1} \\
& +L G B_{m}+D G A T 1_{\mathrm{n}}+L E P_{\mathrm{o}}+F A S N_{\mathrm{p}}+S C D 1_{\mathrm{q}} \\
& +A G P A T 6_{\mathrm{r}}+H Y_{\mathrm{s}}+\text { lac }_{\mathrm{t}}+\text { month }_{\mathrm{u}}+\text { parity }_{\mathrm{v}}+\text { breed }_{\mathrm{w}} \\
& + \text { Sire }_{\mathrm{x}}+\text { COW }_{\mathrm{y}}+\mathrm{e}_{\mathrm{ijkklmnopqrstuwwy}}
\end{aligned}
$$

where $\mathrm{SCS}_{\mathrm{ijklmn}}$, somatic cell score; $C S C 1 S 1_{\mathrm{i}}$, fixed effect of genotype $C S C 1 S 1_{\mathrm{i}}$ (class effect $\mathrm{i}=1,2$ ); $C S N 2 A B_{\mathrm{j}}$, fixed effect of genotype CSN $2 A B$ (class effect $\mathrm{j}=1,2,3$ ); $C S N 2 A 1 A 2_{\mathrm{k}}$, fixed effect of genotype CSN2A1A2 (class effect $\mathrm{k}=1,2,3$ ); $C S N 3_{1}$, fixed effect of genotype CSN3 (class effect $1=1, \ldots, 5$ ); $L G B_{\mathrm{m}}$, fixed effect of genotype $L G B$ (class effect $\mathrm{m}=1,2,3$ ); $D G A T 1_{\mathrm{n}}$, fixed effect of genotype DGAT1 (class effect $\mathrm{n}=1$, 2); $L E P_{0}$, fixed effect of genotype $L E P$ (class effect $o=1,2,3$ ); $F A S N_{\mathrm{p}}$, fixed effect of genotype $F A S N$ (class effect $\mathrm{p}=1,2$ ); $S C D 1_{\mathrm{q}}$, fixed effect of genotype $S C D 1$ (class effect $\mathrm{q}=1,2,3$ ); $A G P A T 6_{\mathrm{r}}$, fixed effect of genotype of AGPAT6 (class effect $\mathrm{r}$ $=1,2,3$ ); $\mathrm{HY}_{s}$, combined fixed effect of farm and year (class effect $s=1, \ldots, 5$ ); lac $c_{\mathfrak{t}}$, fixed effect of the lactation stage (class effect $t=1,2,3$ for day in milk 1 to 99,100 to 200, 201 to 305); month $_{w}$, fixed effect of the calendar month of the year according to the sampling (class effect $u=1, \ldots, 10$ ); parity $_{w}$ fixed effect of lactation parity (class effect $v=1, \ldots, 6$ ); breed $_{w}$, fixed effect of breed (class effect $\mathrm{w}=1,2,3$,); sire $_{\mathrm{x}}$, random effect of the father of the cow; $\operatorname{cow}_{y}$ permanent environment of the cow (repeated measurement); and $\mathrm{e}_{\mathrm{ijklm} \text { nopqrstuwwxy }}$ random residual effect.
Only cows with all genotypes were involved into the computation. The model for the effect of allele was the same as for the genotypes, just there was allele instead of corresponding gene, when allele was fixed effect (class effect $1=1$, 2, 3 for CSN3 alleles, 1, 2 for other alleles). [43].

For post hoc comparisons, the Tukey-Kramer test was used

Phenotype correlations among traits were computed by Pearson correlation coefficients (the CORR Procedure, SAS 9.4). The correlations among SCS on the day of sampling and the percentages of lactose, fat, protein, casein, NFS and urea on the day of sampling were computed involving all measurements.

\section{RESULTS AND DISCUSSION}

Some of the included genes have been studied for a long time, such as caseins, while others have only been studied for a brief time. The analyses were mostly focused on the relation to milk or meat performance, including quality. In this work, we analyzed the impact of the polymorphisms on the microbial quality of the milk; other factors were also tested.

As shown in Table 2, a significant effect of gene polymorphisms on the SCS was rare. Other than genotypes in CSN2 at $p<0.05$, the other genes did not show an impact on the SCS. Similarly, the effect of alleles was mostly nonsignificant. Only the differences between B and C alleles in the CSN1S1 gene, $\mathrm{A}$ and $\mathrm{K}$ alleles in the DGAT1 gene were significant at $\mathrm{p}<0.05$. In CSN1S1 gene, $\mathrm{B}$ allele was better (lower SCS), and the genotype $\mathrm{BB}$ was better than $\mathrm{BC}$ as well, even though nonsignificantly. Regarding DGAT1 gene polymorphisms, the genotype and allele differences had the same tendency, i.e., genotype AA was nonsignificantly better than genotype $\mathrm{KA}$, and allele A was better than allele $\mathrm{K}$. In the CSN2 gene, genotype $A^{1} A^{1}$ was worse than genotypes $A^{1} A^{2}$ and $A^{2} A^{2}$, but the tendency of the allele effect was opposite. However, the difference between alleles was nonsignificant and thus must be interpreted cautiously. For DGAT1, Sanders et al [44] reported the influence of $\mathrm{K}$ and $\mathrm{A}$ alleles and polymorphism in the promoter on the SCS, but their haplotypes did not show a significant impact. In addition, the interaction of the polymorphisms did not affect the SCS. The authors did not find a dominance effect of KA polymorphism on the SCS. Other authors did not find significant differences among DGAT1 genotypes, but the effect of allele substitution was significant [45]. Others refer to the significance of a DGAT1 allele substitution effect for the milk and fat yields and fat and protein percentages, but not for the SCS [46]. Another source refers to the significant influence of the CSN3 polymorphisms on the SCS [47]. However, in this context, the relationship of the SCS and the occurrence of clinical mastitis must be mentioned. In some cases, even when the impact of the polymorphisms 
Table 2. Somatic cell score according to genotype

\begin{tabular}{|c|c|c|c|c|c|}
\hline \multirow[b]{2}{*}{ Gene } & \multirow[b]{2}{*}{ Genotype } & \multirow[b]{2}{*}{$\mathrm{n}^{1)}$} & \multirow[b]{2}{*}{ LSM $\pm S E$} & \multicolumn{2}{|c|}{ p-value } \\
\hline & & & & $\begin{array}{l}\text { Effect of } \\
\text { genotype }\end{array}$ & $\begin{array}{l}\text { Effect of } \\
\text { allele }\end{array}$ \\
\hline \multirow[t]{2}{*}{ CSN1S1 } & BB & 261 & $2.519 \pm 0.653$ & 0.303 & $0.030^{\star}$ \\
\hline & $B C$ & 39 & $2.898 \pm 0.763$ & & $B<C$ \\
\hline \multirow[t]{3}{*}{ CSN2 } & AA & 7 & $1.994 \pm 1.041$ & 0.397 & 0.981 \\
\hline & $A B$ & 108 & $3.092 \pm 0.630$ & & \\
\hline & BB & 185 & $3.040 \pm 0.619$ & & \\
\hline \multirow[t]{3}{*}{ CSN2 } & $A^{1} A^{1}$ & 27 & $3.407^{\mathrm{Aa}} \pm 0.771$ & $0.019 *$ & 0.263 \\
\hline & $A^{1} A^{2}$ & 110 & $2.206^{B} \pm 0.696$ & & $\mathrm{~A}^{1}<\mathrm{A} 2^{2}$ \\
\hline & $A^{2} A^{2}$ & 163 & $2.512^{b} \pm 0.685$ & & \\
\hline \multirow[t]{5}{*}{$\operatorname{CSN}^{2)}$} & AA & 124 & $2.800 \pm 0.691$ & 0.725 & $A: B 0.754$ \\
\hline & $A B$ & 141 & $2.511 \pm 0.674$ & & A:E 0.103 \\
\hline & $A E$ & 11 & $3.078 \pm 0.858$ & & $B: E$ \\
\hline & BB & 14 & $2.408 \pm 0.841$ & & \\
\hline & $\mathrm{BE}$ & 10 & $2.746 \pm 0.841$ & & \\
\hline \multirow[t]{3}{*}{$L G B$} & AA & 15 & $2.658 \pm 0.815$ & 0.819 & 0.921 \\
\hline & $A B$ & 234 & $2.833 \pm 0.712$ & & \\
\hline & BB & 51 & $2.635 \pm 0.711$ & & \\
\hline \multirow[t]{2}{*}{ DGAT1 } & $A A$ & 274 & $2.644 \pm 0.692$ & 0.770 & $0.024^{\star}$ \\
\hline & KA & 26 & $2.773 \pm 0.748$ & & $A<K$ \\
\hline \multirow[t]{3}{*}{ LEP } & MM & 217 & $2.856 \pm 0.685$ & 0.786 & 0.975 \\
\hline & MW & 73 & $2.696 \pm 0.682$ & & \\
\hline & WW & 10 & $2.574 \pm 0.885$ & & \\
\hline \multirow[t]{2}{*}{ FASN } & $A G$ & 89 & $2.609 \pm 0.728$ & 0.454 & 0.618 \\
\hline & GG & 211 & $2.809 \pm 0.668$ & & \\
\hline \multirow[t]{3}{*}{ SCD1 } & $\mathrm{CC}$ & 94 & $2.796 \pm 0.694$ & 0.877 & 0.937 \\
\hline & $\mathrm{TC}$ & 172 & $2.732 \pm 0.676$ & & \\
\hline & TT & 34 & $2.598 \pm 0.766$ & & \\
\hline \multirow[t]{3}{*}{ AGPAT6 } & $\mathrm{CC}$ & 96 & $2.984 \pm 0.631$ & 0.387 & 0.883 \\
\hline & CT & 200 & $3.168 \pm 0.583$ & & \\
\hline & TT & 4 & $1.975 \pm 1.154$ & & \\
\hline
\end{tabular}

LSM, least squared mean; SE, standard error; CSN1S1, casein alpha S1; CSN2, beta-casein; CSN3, kappa-casein; LGB, beta-lactoglobulin; DGAT1, acyl-CoA diacylglycerol transferase 1 ; LEP, leptin; FASN, fatty acid synthase; SCD1, stearoyl CoA desaturase 1; AGPAT6, 1-acylglycerol-3-phosphate 0-acyltransferase 6.

1) $n$ number of samples from cows with a particular genotype.

2) for CSN3 BC and EE genotypes the number of samples was too low to compute LSM, the same for comparison of the effect of $B$ and $E$ alleles.

* Significant at $p<0.05 ; * *$ significant at $p<0.01$.

$\mathrm{a}, \mathrm{b}$ Different letters between genotypes in the same column represent significant differences at $p<0.05$.

$A, B$ Different letters between genotypes in the same column represent significant differences at $p<0.01$.

on some genes on the SCS was stated, their effect on mastitis occurrence was not found $[10,48]$.

To eliminate false positive results, also the Bonferroni correction was used, when the significancy threshold is divided by the number of genes in the analysis, the $\mathrm{p}$ value must be $<0.005$ in our case. This criterion was not met in any polymorphism analysed, it confirms the insignificancy of their effect on the SCS in cow's milk. As the number of analyses from each cow varied from one to five, we made the analysis excluding the cows with only one sample. The results were only negligibly different from those from the all dataset (data not shown).

The combined effect of farm and year was significant, and the differences were substantial (Table 3). These findings emphasize the importance of conditions in particular dairy farms, although in our research, the system of farming was similar: the cows were kept in free stall barnss and were fed by conserved fodder in all farms. At the beginning of lactation, the SCS was lowest, and thereafter, it showed increases in the 2nd and 3rd phases, where the effect of lactation stage was significant (Figure 1). Similarly, the month of the year was significant, as there was a clear tendency for worse microbial quality in April, with the best in June to August (Figure 2). Many authors stated, that season as well as month had a significant effect on the SCC values in bulk milk [49-51]. Their results demonstrated that mastitis risks rise with increasing age or parity and during summer, late spring and early autumn [49]. Similarly Arsoy [51] found higher values of SCC in the summer months, although there are also works where they found the opposite results [50].

We also tested other effects. Breed and lactation parity (Figure 3) were not found to be significant.

Finally, we evaluated the phenotypic correlations of SCS to milk constituents (Table 4). The correlation with lactose content was negative and significant, while the correlation to protein was positive and significant. The correlations of SCS to casein, NFS and urea contents were positive, low and nonsignificant, and the correlations to ketones were negative, low and nonsignificant. The correlations of SCS to citric acid and acetone were also negative, low and nonsignificant, but the $\mathrm{p}$ values were nearing the significance threshold. This was similar to the correlation of SCS to fat percentage, but its correlation was positive. The significant relationship between the SCS and some constituents may indicate that the udder responds to the changing health status. By all means, it is applicable for the lactose percentage. Its correlation coefficient is relatively high and significant. As confirmed by other authors, the worsening health status of the mammary gland reflects the change in lactose content [52]. The authors point to the decreasing dry matter content by reducing the milk lactose and the fat, casein, and calcium in the milk of

Table 3. Effect of different factors on the somatic cell score (p-values)

\begin{tabular}{lc}
\hline Factor & p-value \\
\hline Farm $\times$ year $(\mathrm{HY})$ & $0.020^{\star}$ \\
Lactation stage $^{1)}$ & $0.022^{\star}$ \\
Lactation parity & 0.803 \\
Month of the year $^{2)}$ & $0.027^{\star}$ \\
Breed $^{2}$ & 0.752 \\
\hline
\end{tabular}

1) The lowest in 1st part of the lactation, the highest in the 3rd part.

${ }^{2)}$ Milk of Simmental cows was better than that of Holstein and crossbred cows.

* Significant at $p<0.05$. 


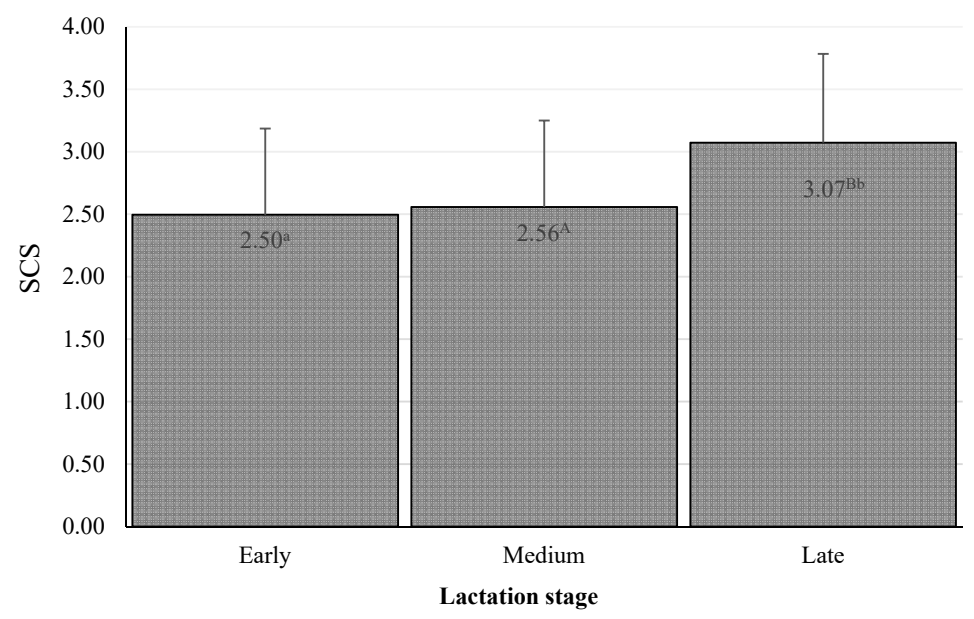

Figure 1. Somatic cell score among lactation stages. The values in columns are means, the bars are standard deviations, SCS is somatic cell score. Early is day 1 to 100, medium day 101 to 200, late day 201 to 305. ${ }^{A, B}$ The differences are significant at $p<0.01$. ${ }^{a, b}$ The differences are significant at $p<0.05$.

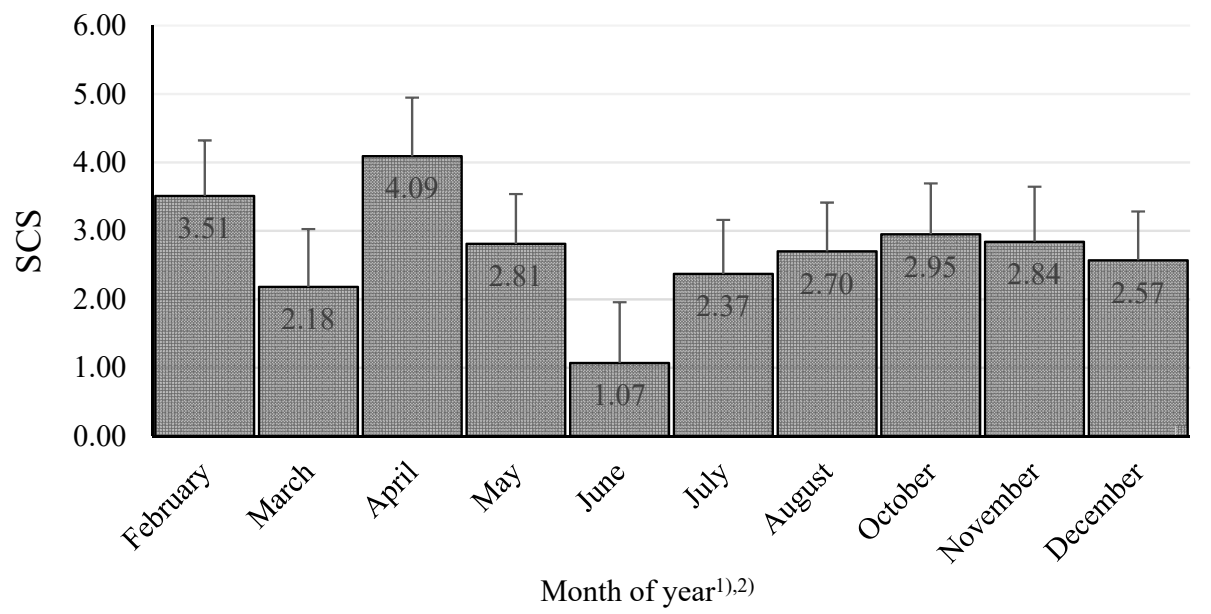

Figure 2. Somatic cell score among months during years. The values in columns are means, the bars are standard deviations, SCS is somatic cell score. ${ }^{1)}$ There were no milk samples in January and September. ${ }^{2)}$ The differences February vs March; April vs March, May, July, August, December; June vs November, December are significant at $p<0.05$. The differences June vs February, April, May, August, October are significant at $p<0.01$.

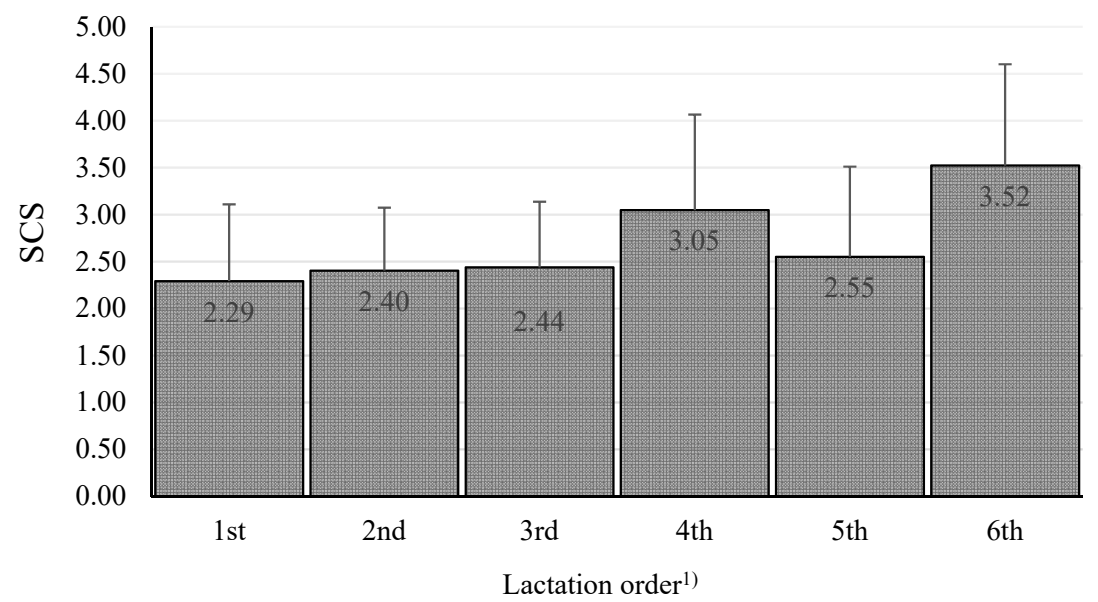

Figure 3. Somatic cell score among lactation orders. The values in columns are means, the bars are standard deviations, SCS is somatic cell score. ${ }^{1)}$ The effect of lactation order was nonsignificant. 
Table 4. Pearson correlations for somatic cell score and content of milk constituents on the day of sampling

\begin{tabular}{lccc}
\hline Items & $\mathbf{n}^{\mathbf{1}}$ & Correlation & p-value \\
\hline Lactose (\%) & 434 & -0.280 & $<0.0001^{\star \star}$ \\
Fat (\%) & 433 & 0.0825 & 0.087 \\
Protein (\%) & 434 & 0.156 & $0.001^{\star \star}$ \\
Casein (\%) & 184 & 0.074 & 0.319 \\
Nonfat solid (\%) & 331 & 0.053 & 0.337 \\
Urea (mg/100 mL) & 434 & 0.001 & 0.983 \\
Citric acid (\%) & 433 & -0.088 & 0.066 \\
Acetone (\%) & 433 & -0.092 & 0.056 \\
Ketones (mmol/L) & 430 & -0.070 & 0.150 \\
\hline
\end{tabular}

${ }^{1)} \mathrm{n}$ number of samples from cows with measurements for the trait. ** Significant at $p<0.01$.

cows with subclinical mastitis. Conversely, the content of whey protein increases, as does the SCC. Mastitis is genetically correlated with lactose yield, and as the amount of the synthesized lactose is the key regulator of milk volume, this result confirms that high-producing cows are more genetically susceptible to mastitis $[53,54]$. Therefore, the lactose content in milk could be potentially used as an indicator to improve udder health.

\section{CONCLUSION}

Generally, the impact of ten polymorphisms in nine genes was weak; only CSN2 genotypes $\mathrm{A}^{1} / \mathrm{A}^{2}$ showed significance, and alleles of CSN1S1 and DGAT1. The importance of farm management for milk quality was confirmed, as was the importance of lactation stage and month of the year. The lactose content in milk is a good indicator of changed health status of the mammary gland.

\section{CONFLICT OF INTEREST}

We certify that there is no conflict of interest with any financial organization regarding the material discussed in the manuscript.

\section{FUNDING}

This research was supported by the Czech Ministry of Agriculture, project MZe NAZV KUS QJ1510336, MZe-RO0719 and by the Grant Agency of the University of South Bohemia, project No. 028/2019/Z.

\section{SUPPLEMENTARY MATERIAL}

Supplementary file is available from: https://doi.org/10.5713/ ab. 20.0720
Supplementary Table S1. Sequences of primers used in the polymerase chain reactions and restriction endonucleases used for genotyping

\section{REFERENCES}

1. Halasa T, Huijps K, Østerds O, Hovegeen H. Economic effects of bovine mastitis and mastitis management: a review. Vet Q 2007;29:18-31. https://doi.org/10.1080/01652176.2007.96 95224

2. Kvapilík J, Hanuš O, Roubal P, et al. Somatic cells in bulk samples and purchase prices of cow milk. Acta Univ Agric Silvic Mendel Brun 2017;65:879-92. https://doi.org/10.11118/ actaun201765030879

3. Kvapilík J, Hanuš O, Bartoň L, Klimešová MV, Roubal P. Mastitis of dairy cows and financial losses: an economic meta-analysis and model calculation. Bulg J Agric Sci 2015; 21:1092-105.

4. Kvapilík J, Hanuš O, Syrůček J, Vyletělová Klimešová M, Roubal P. The economic importance of the losses of cow milk due to mastitis: a meta-analysis. Bulg J Agric Sci 2014; 20:1501-15.

5. Kašná E, Zavadilová L, Štípková M. Genetic evaluation of clinical mastitis traits in Holstein cattle. Czech J Anim Sci 2018;63:443-51. https://doi.org/10.17221/105/2018-CJAS

6. Wolf J, Wolfová M, Stipková M. A model for the genetic evaluation of number of clinical mastitis cases per lactation in Czech Holstein cows. J Dairy Sci 2010;93:1193-204. https:// doi.org/10.3168/jds.2009-2443

7. Zavadilova L, Wolf J, Štípková M, Němcová E, Jamrozik J. Genetic parameters for somatic cell score in the first three lactations of Czech Holstein and Fleckvieh breeds using a random regression model. Czech J Anim Sci 2011;56:25160.

8. Romano GS, Pinto LFB, Valloto AA, Horst JA, Pedrosa VB. Genetic parameters between somatic cell score and production traits for Holstein cattle in Southern Brazil. Rev Colomb Cienc Pecu 2020;33:60-70.

9. Zhang H, Wei Y, Zhang F, et al. Polymorphisms of mannosebinding lectin-associated serine protease 1 (MASP1) and its relationship with milk performance traits and complement activity in Chinese Holstein cattle. Res Vet Sci 2019;124:34651. https://doi.org/10.1016/j.rvsc.2019.04.017

10. Pokorska J, Kułaj D, Ochrem A. Impact of bovine lipocalin-2 haplotype on milk composition, somatic cell score and incidence of mastitis in Polish Holstein-Friesian cattle. J Appl Anim Res 2020;48:51-6. https://doi.org/10.1080/09712119. 2020.1726354

11.Sharma N, Sodhi SS, Kim JH, et al. Molecular cloning of lipocalin-2 into a eukaryotic vector and its expression in bovine mammary epithelial cells as a potential treatment for bovine mastitis. Turk J Biol 2016;40:55-68. 
12.Li M, Gao Q, Wang M, et al. Polymorphisms in fatty acid desaturase 2 gene are associated with milk production traits in Chinese Holstein cows. Animals 2020;10:671. https://doi. org/10.3390/ani10040671

13.Ibeagha-Awemu EM, Akwanji KA, Beaudoin F, Zhao X. Associations between variants of FADS genes and omega-3 and omega- 6 milk fatty acids of Canadian Holstein cows. BMC Genet 2014;15:25. https://doi.org/10.1186/1471-215615-25

14. Proskura WS, Liput M, Zaborski D, et al. The effect of polymorphism in the FADS2 gene on the fatty acid composition of bovine milk. Arch Anim Breed 2019;62:547-55. https:// doi.org/10.5194/aab-62-547-2019

15. Kirsanova E, Heringstad B, Lewandowska-Sabat A, Olsaker I. Identification of candidate genes affecting chronic subclinical mastitis in Norwegian Red cattle: combining genome-wide association study, topologically associated domains and pathway enrichment analysis. Anim Genet 2020;51:22-31. https://doi.org/10.1111/age.12886

16. Amos W, Driscoll E, Hoffman JI. Candidate genes versus genome-wide associations: which are better for detecting genetic susceptibility to infectious disease? Proc R Soc B 2011;278:1183-8. https://doi.org/10.1098/rspb.2010.1920

17.Pighetti GM, Elliott AA. Gene polymorphisms: the keys for marker assisted selection and unraveling core regulatory pathways for mastitis resistance. J Mammary Gland Biol Neoplasia 2011;16:421-32. https://doi.org/10.1007/s10911011-9238-9

18.Liu D, Chen Z, Zhang Z, et al. Detection of genome-wide structural variations in the Shanghai Holstein cattle population using next-generation sequencing. Asian-Australas J Anim Sci 2019;32:320-33. https://doi.org/10.5713/ajas.18. 0204

19. CSN EN ISO/IEC 17025. 2005. Conformity assessment General requirements for the competence of testing and calibration laboratories. Prague, Czech: Czech Normalization Institute; 2005.

20.CSN EN ISO 13366-1 (57 0531). 1998. Milk - Somatic cell count determination - Part 1: Microscopy method. Prague, Czech: Czech Normalization Institute; 1998.

21. CSN EN ISO 13366-2 (57 0531). 2007. Milk - Somatic cell count determination - Part 2: Manual for fluoro-opto-electronic instrument operation. Prague, Czech: Czech Normalization Institute, 2007.

22. Ardicli S, Soyudal B, Samli H, Dincel D, Balci F. Effect of STAT1, OLR1, CSN1S1, CSN1S2, and DGAT1 genes on milk yield and composition traits of Holstein breed. R Bras Zootec 2018;47:e20170247. https://doi.org/10.1590/rbz4720170247

23. Kučerová J, Matějíček A, Jandurová OM, et al. Milk protein genes CSN1S1, CSN2, CSN3, LGB and their relation to genetic values of milk production parameters in Czech Fleckvieh. Czech J Anim Sci 2006;51:241-7.
24. Medrano JF, Sharrow L. Genotyping of bovine beta-casein loci by restriction site modification of polymerase chain reaction (PCR) amplified DNA. J Dairy Sci 1991;74:282.

25. Miluchová M, Gábor M, Trakovická A. Analysis of Slovak Spotted breed for bovine beta casein A1 variant as risk factor for human health. Acta Bioch Pol 2013;60:799-801. https:// doi.org/10.18388/abp.2013_2061

26. Barroso A, Dunner S, Caňón, J. Technical Note: Detection of bovine kappa-casein variants $\mathrm{A}, \mathrm{B}, \mathrm{C}$, and $\mathrm{E}$ by means of polymerase chain reaction-single strand conformation polymorphism (PCR-SSCP). J Anim Sci 1998;76:1535-8. https:// doi.org/10.2527/1998.7661535x

27.Strzalkowska N, Krzyzewski J, Zwierzchowski L, Ryniewicz $Z$. Effects of $\kappa$-casein and $\beta$-lactoglobulin loci polymorphism, cows' age, stage of lactation and somatic cell count on daily milk yield and milk composition in Polish Black-and-White cattle. Anim Sci Pap Rep 2002;20:21-35.

28. Kuhn C, Thaller G, Winter A, et al. Evidence for multiple alleles at the DGAT1 locus better explains a quantitative trait locus with major effect on milk fat content in cattle. Genetics 2004;167:1873-81. https://doi.org/10.1534/genetics. 103.022749

29. Buchanan FC, Fitzsimmons CJ, van Kessel AG, Thue TD, Winkelman-Sim DC, Schmutz SM. Association of a missense mutation in the bovine leptin gene with carcass fat content and leptin mRNA levels. Genet Sel Evol 2002;34:105. https:// doi.org/10.1186/1297-9686-34-1-105

30. Roy R, Ordovas L, Zaragosa P, et al. Association of polymorphisms in the bovine FASN gene with the milk-fat content. Anim Genet 2006;37:215-8. https://doi.org/10.1111/j.13652052.2006.01434.x

31.Inostroza KB, Scheuermann ES, Sepulveda NA. Stearoyl CoA desaturase and fatty acid synthase gene polymorphisms and milk fatty acid composition in Chilean Black Friesian cows. Rev Colomb Cienc Pec 2013;26:263-9.

32. Littlejohn MD, Tiplady K, Lopdell T, et al. Expression variants of the lipogenic AGPAT6 gene affect diverse milk composition phenothypes in Bos taurus. Plos One 2014;9:e85757. https:// doi.org/10.1371/journal.pone.0085757

33. Ali AKA, Shook GE. An optimum transformation for somatic cells concentration in milk. J Dairy Sci 1980;63:487-490. https://doi.org/10.3168/jds.S0022-0302(80)82959-6

34. Shook GE. Approaches to summarizing somatic cell count which improve interpretability. 21st Annual Meeting of the National Mastitis Council: Louisville, KY, USA; 1982. pp. $1-17$.

35. Reneau JK, Appleman RD, Steuernagel GR, Mudge JW. Somatic cell count. An effective tool in controlling mastitis. Agricultural Extension Service, University of Minnesota, AG-FO-0447, 1983:1988.

36. Reneau JK. Effective use of dairy herd improvement somatic cell counts in mastitis control. J Dairy Sci 1986;69:1708-20. 
https://doi.org/10.3168/jds.S0022-0302(86)80590-2

37. Raubertas JK, Shook GE. Relationship between lactation measures of somatic cell content and milk yield. J Dairy Sci 1982;65:419-425. https://doi.org/10.3168/jds.S0022-0302 (82)82207-8

38. Wiggans GR, Shook GE. A lactation measure of somatic cell count. J Dairy Sci 1987;70:2666-72. https://doi.org/10.3168/ jds.S0022-0302(87)80337-5

39. Ghasemi Z, Aslaminejad AA, Tahmoorespur M, Rokouei M, Faraji Arough H. Association of somatic cell score with production traits in Iranian Holstein cows. Iranian J Appl Anim Sci 2013;3:491-5.

40. Chegini A, Ghavi Hossein-Zadeh N, Hosseini-Moghadam $H$, Shadparvar AA. Effect of static cell count on milk fat and protein in different parities and stages of lactation in Holstein cows. Acta Agric Slov 2017;110:37-45. https://doi.org/10. 14720/aas.2017.110.1.5

41.Costa A, Lopez-Villalobos N, Visentin G, De Marchi M, Cassandro M, Penasa M. Heritability and repeatability of milk lactose and its relationships with traditional milk traits, somatic cell score and freezing point in Holstein cows. Animal 2019;13:909-16. https://doi.org/10.1017/S1751731118002094

42. Costa A, Fuerst-Waltl B, Fuerst C, Mészáros G, Penasa M, Sölkner J. Genetic association between somatic cell score and milk lactose in early- to mid-lactation of first carving Fleckvieh cows. J Central Eur Agric 2018;19:791-7. https:// doi.org/10.5513/JCEA01/19.4.2347

43. Haynes W. Tukey's Test. In: Dubitzky W, Wolkenhauer O, Cho KH, Yokota H, editors. Encyclopedia of Systems Biology. New York, USA: Springer-Verlag; 2013.

44. Sanders K, Bennewitz J, Reinsch N, et al. Characterization of the DGAT1 mutations and the CSN1S1 promoter in the German Angeln dairy cattle population. J Dairy Sci 2006;89: 3164-3174. https://doi.org/10.3168/jds.S0022-0302(06)72 590-5

45. Mao YJ, Chen RJ, Chang LL, et al. Effects of SCD1- and DGAT1-genes on production traits of Chinese Holstein cows located in the Delta Region of Yangtze River. Livest Sci 2012; 145:280-6. https://doi.org/10.1016/j.livsci.2011.12.019 46. Mömke S, Brade W, Distl O. Co-segregation of quantitative trait loci (QTL) for milk production traits and length of productive life with QTL for left-sided displacement of the abomasum in German Holstein dairy cows. Livest Sci 2011; 140:149-54. https://doi.org/10.1016/j.livsci.2011.03.001

47. Viale E, Tiezzi F, Maretto F, De Marchi M, Penasa M, Cassandro M. Association of candidate gene polymorphisms with milk technological traits, yield, composition, and somatic cell score in Italian Holstein-Friesian sires. J Dairy Sci 2017;100: 7271-81. https://doi.org/10.3168/jds.2017-12666

48. Dusza M, Pokorska J, Makulska J, Kulaj D, Cupial M. L-selectin gene polymorphism and its association with clinical mastitis, somatic cell score, and milk production in Polish HolsteinFriesian cattle. Czech J Anim Sci 2018;63:256-62. https:// doi.org/10.17221/96/2017-CJAS

49. Erdem H, Atasever S, Kul E. Some environmental factors affecting somatic cell count of Holstein cows. J Appl Anim Res 2007;32:173-76. https://doi.org/10.1080/09712119.2007. 9706871

50.Dobranic V, Njari B, Samardzija M, Miokovic B, Resanovic R. The influence of the season on the chemical composition and the somatic cell count of bulk tank cow's milk. Vet Arch 2008;78:235-42.

51. Arsoy HD. The effect of year, month, region, and herd size on bulk tank somatic cell and standard plate count, and the determination of optimum herd size in the intensive Holstein Friesian dairy farms in the Turkish republic of cyprus. Turkish J Vet Anim Sci 2020;44:1232-42. https://doi.org/10.3906/ vet-2005-124

52. Fedotov SV, Belozertseva NS, Udalov GM. Peculiarities of protein composition of milk of black-motley cows with subclinical mastitis (in Russian). Veterinariya 2018; Issue 2: 34-7.

53. Costa A, Egger-Danner C, Meszaros G, et al. Genetic associations of lactose and its ratios to other milk solids with health traits in Austrian Fleckvieh cows. J Dairy Sci 2019; 102:4238-48. https://doi.org/10.3168/jds.2018-15883

54.Costa A, Lopez-Villalobos N, Sneddon NW, et al. Invited review: Milk lactose - Current status and future challenges in dairy cattle. J Dairy Sci 2019;102:5883-98. https://doi.org/ 10.3168/jds.2018-15955 